\title{
Mechanical properties and permeability of red mud-blast furnace slag-based geopolymer concrete
}

\author{
Xiangzhou Liang ${ }^{1,2} \cdot$ Yongsheng $\mathrm{Ji}^{1,3}$
}

Received: 28 September 2020 / Accepted: 19 December 2020 / Published online: 7 January 2021

(c) The Author(s) 2020 OPEN

\begin{abstract}
Red mud, a by-product of alumina production, has a great impact on the environment due to its high alkalinity. In this paper, two-part geopolymer mortar was synthesized by combining red mud and blast furnace slag (BFS) to obtain optimized compressive strength and flexural strength for construction materials. Geopolymer concrete was prepared with the cementitious material in the concrete replaced by geopolymer mortar. Mechanical properties, permeability and microscopic properties of geopolymer concrete were measured. The results showed that the compressive strength grade of concrete prepared with geopolymer concrete can reach 54.43 MPa indicating that the geopolymer concrete can be used as materials for load-bearing members in structures. Due to lower total porosity and better pore structure, the permeability resistance of geopolymer concrete was significantly better than ordinary concrete. Microscopic analysis indicated that a large amount of aluminosilicate reaction products was generated in a geopolymer by the reaction of $\mathrm{OH}^{-}$with the aluminosilicate components in red mud and BFS in a strongly alkaline environment. The surface [SiO4] ${ }^{4-}$ and $[\mathrm{AlO} 4]^{4-}$ tetrahedrons form chemical bonds through dehydroxylation, which is the direct reason for their high strength and determines their excellent physical and chemical properties.
\end{abstract}

Keywords Red mud. Geopolymer concrete $\cdot$ Mechanical properties $\cdot$ Permeability $\cdot$ Microscopic properties

\section{Introduction}

Red mud, characterized by a high-water content and complex composition varying with bauxite composition, production process, dehydration and storage period, is a kind of hazardous solid waste by-product of alumina production with strong alkalinity [1]. Global production of red mud exceeds 117 million tons per year [2]. Typically, about 1-1.5 tons of red mud remain from the production of 1 ton of alumina and the utilization rate of red mud is only about $15 \%[3,4]$. The high alkalinity of red mud is harmful to the surrounding water, ground, air and other environments. Therefore, how to deal with and recycle red mud is an urgent problem to be solved. Some scholars have proposed different red mud recovery schemes, such as reuse of red mud as a catalyst [5], adsorbent [6] and soil improver [7]. However, the above methods were expensive and had limited ability to recover large amounts of red mud. At present, the main dealing method of red mud is still landfill, which will cause a lot of waste of land. Geopolymer, with industrial waste as its raw materials and low $\mathrm{CO}_{2}$ emissions, is an alternative to cement materials for building materials [8]. Geopolymer is a basic aluminosilicate material, composed of $\mathrm{AlO}_{4}$ and $\mathrm{SiO}_{4}$ cross-linked structure [9]. It is usually synthesized from materials rich in silicon and aluminum, which can promote the formation of aluminosilicate in a high alkalinity environment [10].

$\triangle$ Yongsheng Ji, piaoxuecumt@foxmail.com | ${ }^{1}$ Sch Civil Engn \& Mech, Yanshan University Yanshan Univ, Qinhuangdao, China. ${ }^{2}$ JiangSu Collaborative Innovation Center for Building Energy Saving and Construction Technology, Xuzhou 221116, Jiangsu, China. ${ }^{3}$ State Key Laboratory for Geomechanics \& Deep Underground Engineering, China University of Mining and Technology, Xuzhou 221116, Jiangsu, China. 
As a material with high basicity and high aluminum content, red mud is a suitable geopolymer precursor. In recent years, much work has been carried out on a red mud-based geopolymer. Different proportions of red mud and rice husk waste were prepared as a geopolymer by $\mathrm{He}$ et al. [11]. It is found that the compressive strength characteristics of most geopolymers were similar to OPC, but their mechanical properties were very complex and were determined by many factors, including alkalinity, mixing ratio, curing time and particle size. Kumar [12] used red mud to partially replace $0-40 \%$ fly ash and synthesized a geopolymer at room temperature. The effects of red mud content on geopolymer reaction, structure and performance were studied. After adding red mud, the strength of all test pieces was improved, but only in the samples containing 5-20\% red mud, the setting time and compressive strength increased. Structural characterization showed that the reaction rate was related to the concentration of sodium hydroxide, but the development of mechanical properties was related to the dense microstructure formed by the combined effect of sodium hydroxide concentration, silicate solubility and the presence of iron oxide. Kaya's research [13] on red mud metakaolin-based geopolymer revealed the systematic addition of red mud into a geopolymer system resulted in a constant loss of intensity and increased broadening of the main features in XRD and FTIR spectra. Increasing red mud incorporation in this system resulted in a nearly monotonous decreasing trend in the compressive strength. One-part "just add water" geopolymer binders are synthesized through the alkali-thermal activation of the red mud by Ke [14]. They found that red mud is an effective precursor to produce one-part geopolymer binders, via thermal and alkali-activation processes. Choo et al. [15] made one-part mix alkaliactivated materials with high unburnt carbon particles as the aluminosilicate precursor and red mud as the Sodium hydroxide source. In their study, the unconfined compressive strength (UCS) of red mud-activated fly ash with the content of red mud was studied. However, a one-part geopolymer has low compressive strength with the maximum UCS of around 1.0 MPa. Based on the above red mud geopolymer preparation methods, some scholars carried out some work in enhancing the strength of geopolymer. Ye et al. $[16,17]$ investigated a one-part geopolymer synthesized from the Bayer method through an alkali-thermal activation process. By adding another silica-rich material silica fume with high activity, the compressive strength deterioration problem of the one-part geopolymer synthesized from Bayer red mud was solved. Hu et al. [18] studied the possibility of utilizing one type of red mud along with three types of fly ash as the source material to produce the geopolymer cured at both ambient and elevated temperatures. They found that compressive strength of $15.2 \mathrm{MPa}$ was obtained during a standard period of ambient temperature curing, at a significantly low sodium hydroxide concentration compared to other class F-based geopolymer. Red mud-metakaolin-based geopolymer activated by sodium silicate and sodium hydroxide cured for 28 days with a compressive strength of $10 \mathrm{MPa}$, comparable water absorption and density were synthesized by Hajjaji [19].

The permeability of the geopolymer was mainly carried out by the chloride ion penetration test. Ribeiro et al. [20] tested the chloride ion diffusion of geopolymer with a red mud content of $30 \%$ by the ASTM C-1202 method. It was found that the higher the red mud content, the lower the corrosion rate. In this work, vacuum saturation was not used; instead, the samples were immersed in water for $24 \mathrm{~h}$ before testing. However, the dissolution of the free alkali in red mud will interfere with the results of electrical properties. Furthermore, it remains to be studied whether the chloride ion diffusion test method suitable for traditional concrete is still applicable to RMGC. Diaz et al. [21] carried out a natural diffusion test to detect the diffusion of chloride ions in red mud-based geopolymer. However, the test time (two months of continuous natural observation) was too long to apply to engineering practice.

Although the current research focuses on the preparation of geopolymer and achieves some beneficial results, the research on the strength and durability of geopolymer concrete is still insufficient. In order to recycle the red mud and use it in the bearing member of the structure, this paper studied the strength (compressive strength and splitting tensile strength) and the impermeability of the red mud-BFS geopolymer concrete. Microscopic measurement methods were also carried out for the pore structure and minerals of the red mud-BFS-based geopolymer.

\section{Materials and methods}

\subsection{Materials}

Red mud, BFS, sodium hydroxide flakes, river sand, coarse aggregate and tap water were the main constituents of the geopolymer concrete. The red mud produced by the sintering process was collected from Longmen coal industry co., LTD, China. BFS was collected from Xuzhou Cheng Yi cement factory. As shown in Fig. 1, the size distribution of red mud and BFS was obtained by using Laser Diffraction analysis. The $96 \%$ pure sodium hydroxide flake was supplied by Hui Xin industry and trade Co., LTD., China. The slaked lime powder obtained by fully digesting and drying the quicklime powder was initially grounded to pass through the $0.08-\mathrm{mm}$ sieve. The fine aggregate produced by Yi He river in Xu Zhou, China, with a fineness modulus of 2.79 , moisture content of $1 \%$, an apparent density of 
(a)

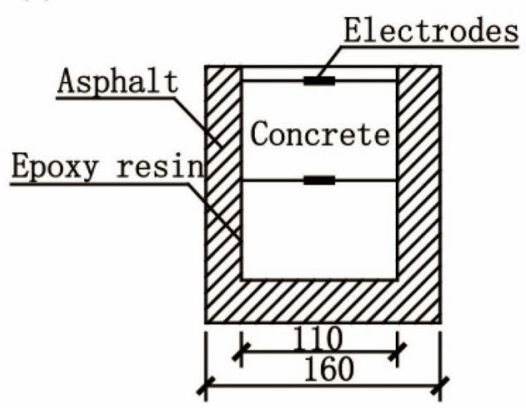

(c)

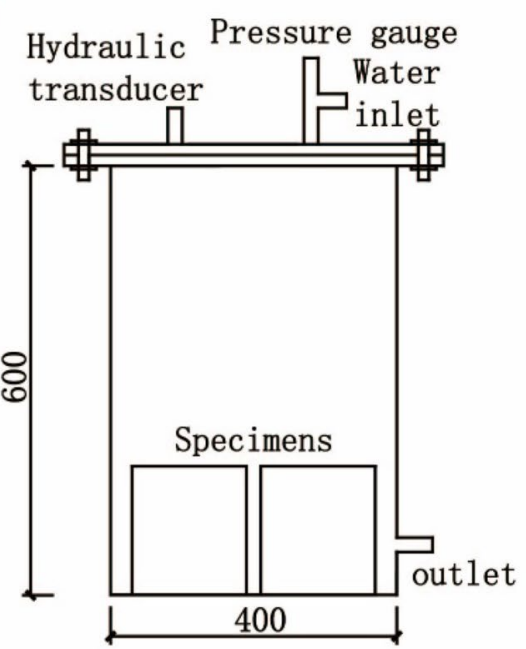

(b)

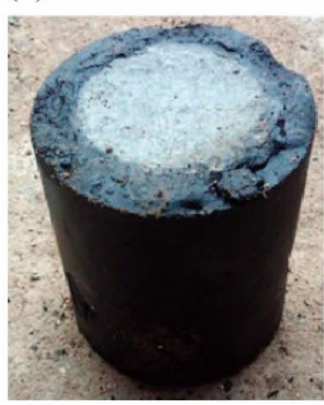

(d)

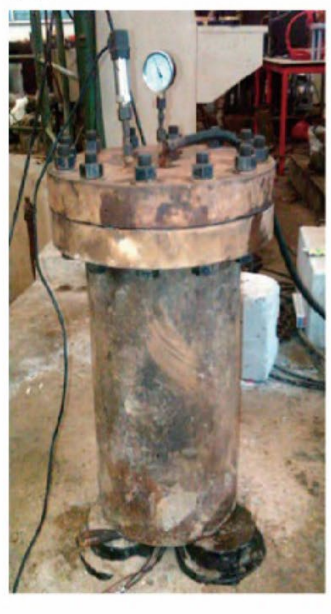

(e)

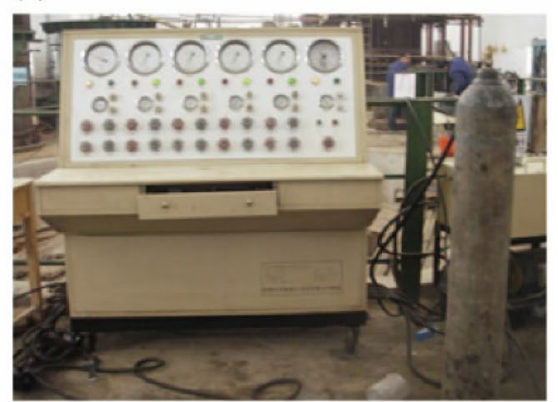

(f)

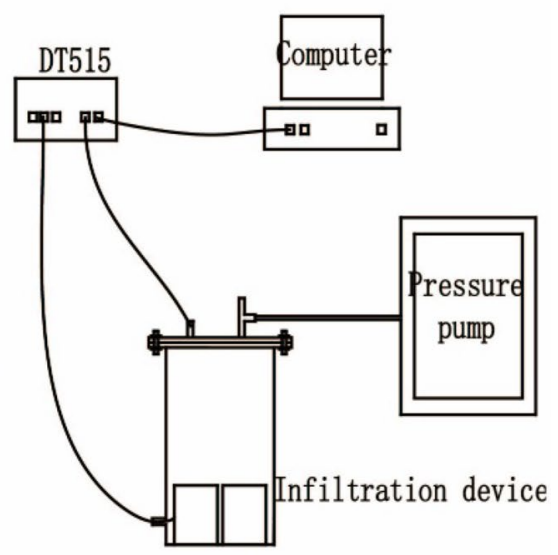

Fig. 1 Impermeability test

$2.64 \mathrm{~g} / \mathrm{cm}^{3}$, was used after being washed and dried. Basalt natural coarse aggregate with a particle size of 5-20 mm, 24-h water absorption of $1.7 \%$, an apparent density of $2.86 \mathrm{~g} / \mathrm{cm}^{3}$ was used. Ordinary Portland cement (OPC) P.O 42.5 Grade was used as a cementing material for ordinary concrete.

\subsection{Pretreatment of materials}

Massive red mud was first crushed with a jaw crusher and then dried in an oven at $105^{\circ} \mathrm{C}$ to constant weight. Then dried red mud was ground to pass 200 mesh sieves. The red mud, gypsum and lime (RGL) were mixed uniformly according to a ratio of 17: 2: 1 and placed in a high-temperature electric furnace for calcination.

\subsubsection{Synthesis of geopolymer mortar}

Sodium hydroxide was dissolved in tap water to prepare an activator. Then, the solid phase consisting of RGL and BFS was mechanically blended with the activator evenly to obtain a homogeneous paste. The mass ratio of the solid phase, tap water and fine aggregate was 1: 0.5: 3 .
Different ratios of RGL, BFS and sodium hydroxide are shown in Table 1. Then, pastes were molded in plastic molds $\left(40 \mathrm{~mm} \times 40 \mathrm{~mm} \times 160 \mathrm{~mm}\right.$ ) and cured at $20 \pm 1{ }^{\circ} \mathrm{C}$ and relative humidity of $95 \%$ for $24 \mathrm{~h}$. The binders were then demolded and cured again under the same condition for 28 days. Compressive strength and flexural strength tests were carried out.

Table 1 Experiment grouping of alkali red mud-BFS plastic mortar specimens

\begin{tabular}{lll}
\hline No & RGL:BFS & $\begin{array}{l}\text { Sodium } \\
\text { hydrox- } \\
\text { ide wt } \%\end{array}$ \\
\hline $1-1-1$ & $4: 1$ & 8 \\
$1-1-2$ & & 10 \\
$1-2-1$ & $2: 1$ & 8 \\
$1-2-2$ & & 10 \\
$1-3-1$ & $1: 1$ & 4 \\
$1-3-2$ & & 6 \\
$1-3-3$ & & 8 \\
$1-3-4$ & & 10 \\
\hline
\end{tabular}




\subsubsection{Synthesis of red mud-BFS-based geopolymer concrete}

The concrete mix ratio of cement, tap water, fine aggregate and coarse aggregate was 1: 0.47: 1.28: 2.38. A water/ cement ratio of 0.47 was used in this study to prepare M30 grade concrete. In the red mud-BFS-based geopolymer concrete, red mud, lime and BFS were used to replace the cement in accordance with the optimal mixing ratio and the mass content of the activator sodium hydroxide was $8 \%$. The red mud-BFS-based geopolymer concrete specimens and ordinary concrete specimens were tested for compressive strength and split tensile strength at 3 days, 7 days, 14 days and 28 days, respectively. The size of the specimen is $100 \mathrm{~mm} \times 100 \mathrm{~mm} \times 100 \mathrm{~mm}$. There are a total of 16 groups including geopolymer concrete groups and ordinary concrete groups, with 6 specimens in each group (three for the compression test and three for the split tensile test).

\subsubsection{Impermeability test}

Two sizes of PVC formwork $(\varphi 110 \times 150 \mathrm{~mm}$ and $\varphi 160 \times 180 \mathrm{~mm}$ ) were used as the formwork for concrete casting and the formwork for sealing the circumference and bottom of the concrete specimens, respectively. The arrangement of the electrodes in the concrete specimen is shown in Fig. 1a. A $3 \times 5 \mathrm{~mm}$ copper sheet was selected as the electrode and welded on the enameled wire to test the resistance change in the concrete. In order to ensure that water permeates along one side of the concrete during the test, epoxy resin and asphalt are selected to seal the side and bottom surfaces of the specimens, as shown in Fig. $1 \mathrm{~b}$.

The permeation test device consists of a water storage cavity and a cover plate. A sealing groove was set on the annular surface where the cover plate and the cavity contact. A seal ring was arranged, and the seal ring was coated with butter. The upper and lower cover plates with 12 high-strength bolts were compacted to seal the device. The test specimen was placed in the cavity, and the lead was led out from the outlet and sealed with epoxy resin. The upper cover has three interfaces for pressure gauges, hydraulic sensors and water inlet pipes, as shown in Fig. 1c, d. The penetration test system is shown in Fig. 1e, f, which can dynamically reflect the penetration of concrete. The penetration height method and the resistance test method were used in the test system. The electrode wire was connected to the corresponding test channel of the DT515 sensor, the resistance value between the two concrete embedded electrodes was displayed and recorded every minute through the computer.

\subsubsection{Microscopic characterization methods}

After the compressive strength test, the crushed samples were immersed in alcohol for the materials characterization test. The sample powder was dried for microscopic examination. A part of the crushed samples was ground in an agate mortar until it passes through a 325 mesh sieve for XRD and FT-IR. The other part of the crushed samples were cut into $10 \mathrm{~mm} \times 10 \mathrm{~mm}$ for SEM and MIP. The main chemistry of the powder of red mud and BFS ( $>325$ mesh) was studied using the $\mathrm{X}$-ray fluorescence (X-Ray Fluorite Spectroscopy S8 Tiger) as shown in Table 2. Mercury intrusion porosimetry (MIP) was performed using a Mercury porosimeter from Micromeritics (PoreMaster 33) to observe the pore size distribution and cumulative pore volume of the geopolymer concrete and the ordinary concrete. Morphology of the geopolymer concrete and the ordinary concrete were characterized by scanning electron microscopy (SEM, Sirion 200, FEI Co., Netherlands). The main phase compositions of the geopolymer were analyzed by XRD (D8 ADVANCE) with Cu Ka radiation at $40 \mathrm{~mA}$ and $40 \mathrm{kV}$. The structure of chemical bonds in red mud was determined by Nexus 670 Fourier transform infrared spectrophotometer of Nicolet.

\section{Experimental result and discussion}

\subsection{Compressive strength and flexural strength of geopolymer mortar}

Compressive strength and flexural strength of geopolymer mortar are shown in Fig. 2. According to the provisions of GB175-2007 (General guidelines for Portland cement in China), the compressive strength of P.O 42.5 cement mortar specimens at 3 days and 28 days should not be lower than $17.0 \mathrm{MPa}$ and $42.5 \mathrm{MPa}$ and the flexural strength should not be lower than $3.5 \mathrm{MPa}$ and $6.5 \mathrm{MPa}$, respectively. As is seen from Fig. 2, early flexural strength (3 days) of geopolymer mortar specimens developed rapidly and some even reached the 28-day flexural strength requirement of P.O 42.5 cement mortar Besides; the compressive
Table 2 The main chemistry of the red mud and BFS

\begin{tabular}{lllllllllll}
\hline No & $\mathrm{SiO}_{2}$ & $\mathrm{Al}_{2} \mathrm{O}_{3}$ & $\mathrm{Fe}_{2} \mathrm{O}_{3}$ & $\mathrm{CaO}$ & $\mathrm{MgO}$ & $\mathrm{Na}_{2} \mathrm{O}$ & $\mathrm{K}_{2} \mathrm{O}$ & $\mathrm{Ti}_{2} \mathrm{O}$ & $\mathrm{SnO}$ & Loss \\
\hline Red mud & 16.98 & 13.35 & 7.43 & 30.29 & 1.5 & 2.82 & 0.38 & 2.29 & - & 24.96 \\
BFS & 31.35 & 18.65 & 0.57 & 34.65 & 9.31 & - & - & - & 0.41 & 0.70 \\
\hline
\end{tabular}




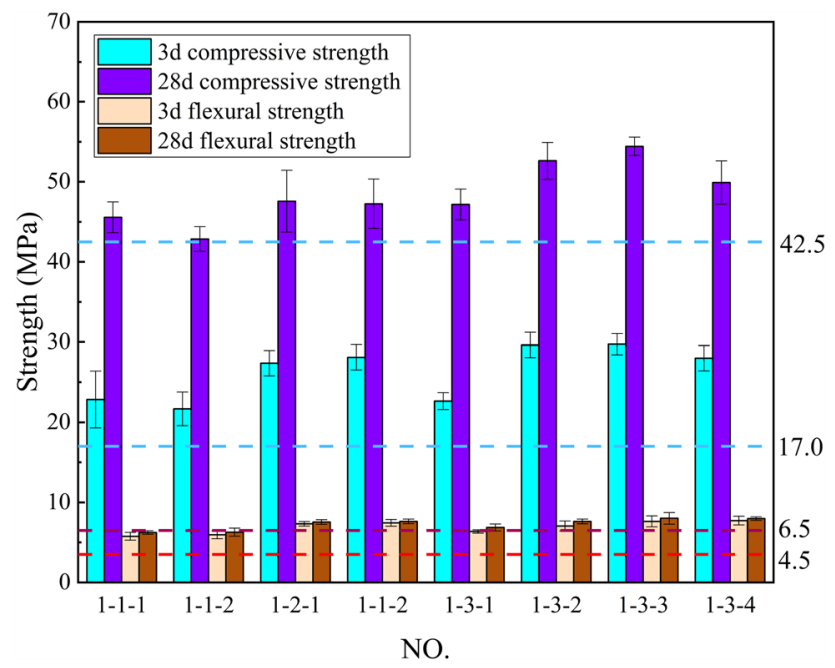

Fig. 2 Compressive strength and flexural strength of geopolymer mortar

strength also shows early strength characteristics. compressive strength of geopolymer mortar specimens at 3 days reached about $50 \%$ to $60 \%$ compressive strength at 28 days; when the sodium hydroxide content of the stimulant is $8 \%$. Comparing the data in Fig. 2, the 1-3-3 group has the highest flexural and compressive strength, with sodium hydroxide content $8 \%$.

\subsection{Compressive strength and splitting tensile strength of geopolymer concrete and ordinary concrete}

To study the mechanical properties of geopolymers, the 1-3-3 group was selected for comparison with ordinary concrete. It is seen from Fig. 3 that the early strength of geopolymer concrete develops rapidly and the

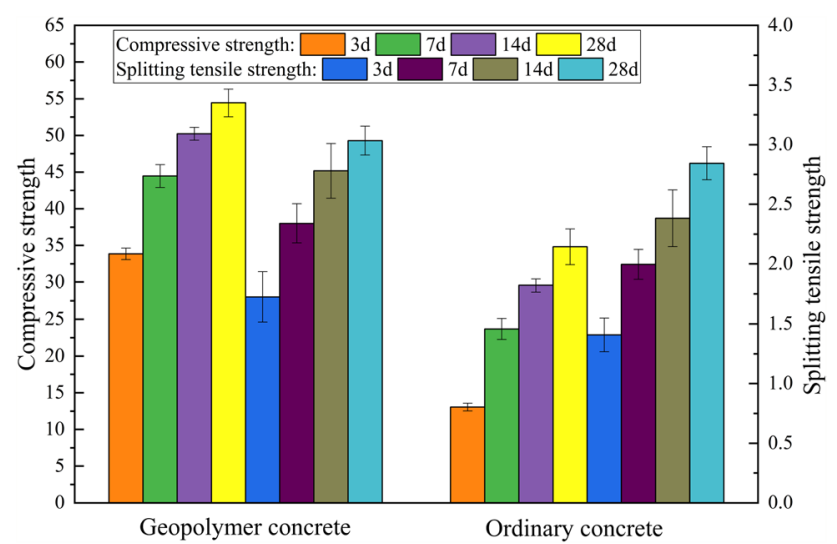

Fig. 3 Compressive strength and splitting tensile strength of geopolymer concrete and ordinary concrete compressive strength of geopolymer concrete at 3 days, 7 days and 14 days reach $62.2 \%, 81.7 \%$ and $92.3 \%$ of that at 28 days, respectively. In contrast, the compressive strength of ordinary concrete at 3 days, 7 days and 14 days reached $37.5 \%, 68.0 \%$ and $84.9 \%$ of that at 28 days, respectively.

Similarly, the splitting tensile strength of geopolymer concrete develops rapidly and the strengths at 3 days, 7 days and 14 days reached $56.85 \%, 77.11 \%$ and $91.64 \%$ of that at 28 days, respectively. On the other side, the splitting tensile strength of ordinary concrete at 3 days, 7 days and 14 days reached $49.52 \%, 70.20 \%$ and $83.79 \%$ of that at 28 days, respectively.

\subsection{Permeability}

After the geopolymer concrete and ordinary concrete were continuously pressurized for $1650 \mathrm{~min}$ in the penetration test device, the resistance changes of the two types of concrete during the penetration test are shown in Fig. 4. During the penetration process, the resistance between the electrodes of the test piece decreased continuously as the water content increased. When the concrete pores between the two electrodes were saturated with water, the ions in the water reached infiltration equilibrium and the resistance value tended to be stable. The moment when the resistance value started to stabilize was the time when the peak of the water head expanded to the position of the lower test electrode, which was the time it cost to penetrate the distance of $80 \mathrm{~mm}$.

As shown in Fig. 4, the resistance value between the electrodes of the geopolymer concrete during the penetration process eventually stabilizes at about $600 \Omega$. Although the resistance still showed a downward trend during 800-1000 min, considering the influence of temperature

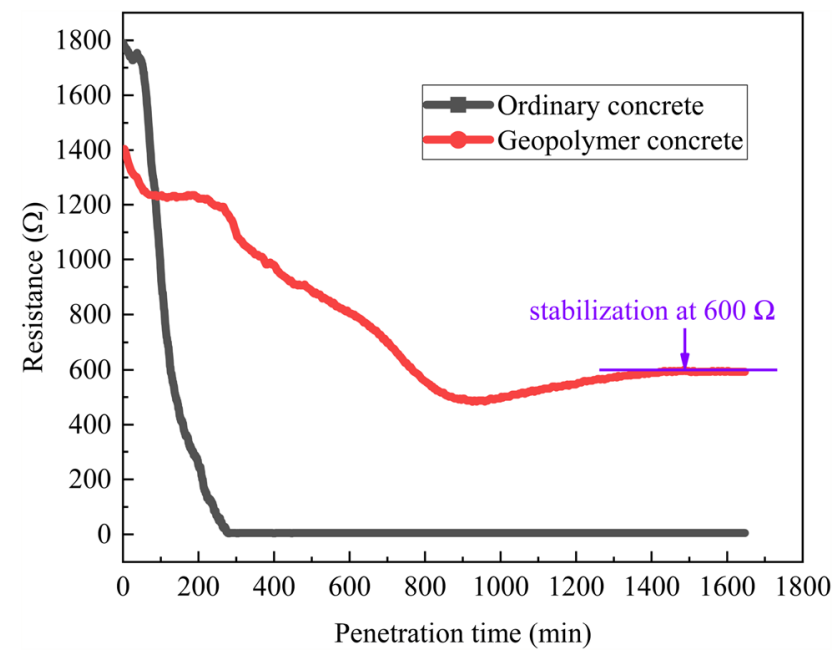

Fig. 4 Penetration time vs. Resistance 
and pore solution changes, the time to penetrate the geopolymer concrete at $80 \mathrm{~mm}$ was $770 \mathrm{~min}$, and the resistance between the embedded electrodes in the geopolymer concrete was $597.45 \Omega$. The change in resistance between the embedded electrodes in ordinary concrete was different from that in geopolymer concrete. The resistance value of ordinary concrete was finally zero because of the result of the difference in the pore structure and ion in the pore solution of the two types of concrete. Finally, the resistance between the two concrete electrodes eventually tended to a stable value. According to the test results, the time for water to penetrate the ordinary concrete at $80 \mathrm{~mm}$ was $280 \mathrm{~min}$, and the resistance between the electrodes was zero.

After the 1650 min penetrating process, the pressure of the test specimens was released, and the specimens were taken out. The asphalt wrapped on the surface of the test specimens was then removed, and the specimens were split by the press. Pieces of concrete are used to measure the water absorption, and then the permeability coefficient was calculated. The penetration test results of the geopolymer concrete, and the ordinary concrete are shown in Table 3.

Because the permeability coefficient of concrete is quite small, the seepage process conforms to Darcy's law [22-24], so the calculation of the seepage velocity $v$ is shown in Eq. (1):

$v=k \cdot J=\frac{k P}{h}$

where, the water pressure is $P$; the penetration depth is $h$; the hydraulic gradient is $J(J=P / h)$.

Since the seepage process is continuous, the increment of water permeability is as shown in Eq. (2):

$d_{q}=\alpha A d_{h}=A v d_{t}$

where, the seepage time increment is $d_{t}$; the water surface rise increment is $d_{h}$; the concrete porosity is $\alpha$.

Both sides of the equation were integrated at the same time, and Eq. (3) was obtained:

$k=\frac{\alpha H^{2}}{2 T P}$

where, $H$ is the vertical penetration depth at the end time $T$ of the seepage experiment.

Table 3 Penetration test results of the geopolymer concrete and the ordinary concrete

\begin{tabular}{llll}
\hline Type of concrete & $\begin{array}{l}\text { Osmotic } \\
\text { pres- } \\
\text { sure (MPa) }\end{array}$ & $\begin{array}{l}\text { Penetration } \\
\text { time (min) }\end{array}$ & Absorption \% \\
\hline Geopolymer concrete & 4.4 & 770 & 7.11 \\
Ordinary concrete & 4.4 & 280 & 8.01 \\
\hline
\end{tabular}

According to Eq. (3), the permeability coefficients of the geopolymer concrete and the ordinary concrete are $1.1 \times 10^{-14} \mathrm{~m} / \mathrm{s}$ and $3.4 \times 10^{-14} \mathrm{~m} / \mathrm{s}$, respectively. According to the test results, the permeability of ordinary concrete was much greater (3.1 times) than that of the geopolymer concrete. Therefore, the impermeability of geopolymer concrete is better than that of ordinary concrete. After the permeability coefficient is obtained, the penetration distance of water in the concrete under certain pressure and time can be calculated according to Eq. (3), which is of great significance for certain concrete structures with special impermeability requirements.

\subsection{Microscopic analysis}

Particle size distribution curves of red mud, BFS and cement are shown in Fig. 5. Particle sizes $X_{n}(n=10,50$, 90) and $X_{\text {av }}$ standard for the cumulative particle size and the average particle size of the particle group as shown in Table 4. The average particle size of red mud was $2.973 \mu \mathrm{m}$, while the average particle size of BFS and cement was $15.228 \mu \mathrm{m}$ and $16.592 \mu \mathrm{m}$, respectively. The particle size range of red mud is mainly concentrated at 0.895-6.509 $\mu \mathrm{m}$, while the particle size ranges of BFS and cement are 1.946-31.945 $\mu \mathrm{m}$ and 1.573-38.177 $\mu \mathrm{m}$, respectively. It can be found that the particle sizes of BFS
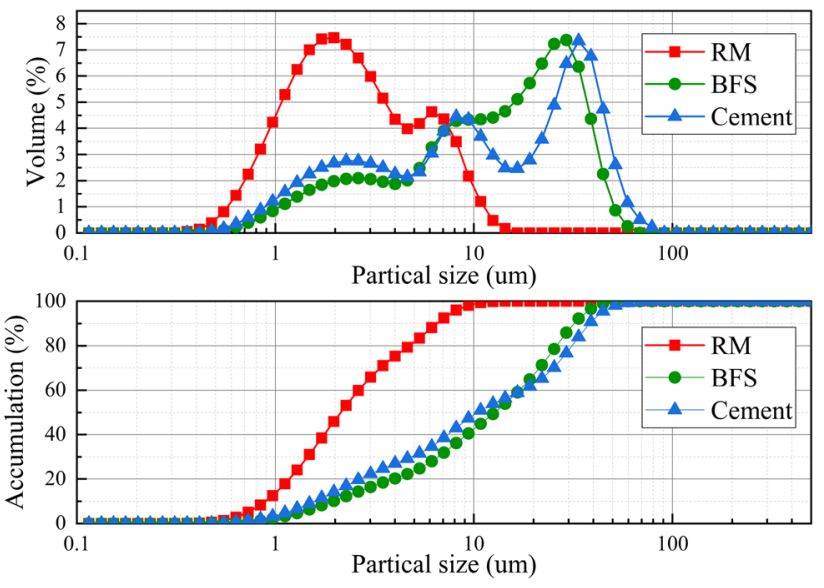

Fig. 5 Particle size distribution curves of red mud, BFS and cement

Table 4 Particle size distribution parameters of red mud, BFS and cement $(\mu \mathrm{m})$

\begin{tabular}{llrrr}
\hline Type & $X_{10}$ & \multicolumn{1}{c}{$X_{50}$} & \multicolumn{1}{c}{$X_{90}$} & \multicolumn{1}{c}{$X_{\mathrm{av}}$} \\
\hline Red mud & 0.895 & 2.133 & 6.509 & 2.973 \\
BFS & 1.946 & 12.760 & 31.945 & 15.228 \\
Cement & 1.573 & 10.389 & 38.177 & 16.592 \\
\hline
\end{tabular}


and cement are similar, while the particle size of red mud is significantly smaller than that of BFS and cement.

The distribution of pores in concrete is very wide and the pore size ranges from $10^{-7} \mathrm{~mm}$ to $10^{-2} \mathrm{~mm}$. According to the size of the pore size, the pore size of concrete can be divided into gel pores $\left(<10^{-5} \mathrm{~mm}\right)$, excessive pores $\left(10^{-5}-10^{-4} \mathrm{~mm}\right)$, capillary pores $\left.10^{-4}-0^{-3} \mathrm{~mm}\right)$ and large pores $\left(>10^{-3} \mathrm{~mm}\right)$. Increasing gel pores, reducing transition pores, eliminating capillary pores and macropores are very beneficial for improving the mechanical properties and durability of concrete. The porosity and pore size distribution of geopolymer concrete and ordinary concrete was measured by the mercury intrusion method, as shown in Fig. 6 and Table 5.

The total porosity of geopolymer concrete was only $15.88 \%$, while the total porosity of ordinary concrete reached $33.35 \%$, which was twice the total porosity of geopolymer concrete. In terms of pore size distribution, gel pores accounted for $36.09 \%$ of the total pores in geopolymer concrete, while ordinary concrete had fewer gel pores, only $6.12 \%$. The pore size distribution of ordinary concrete was mainly transitional pores, capillary pores and macropores, which were $55.56 \%$ and $38.32 \%$ of the total pores, respectively. In contrast, the relative proportions of

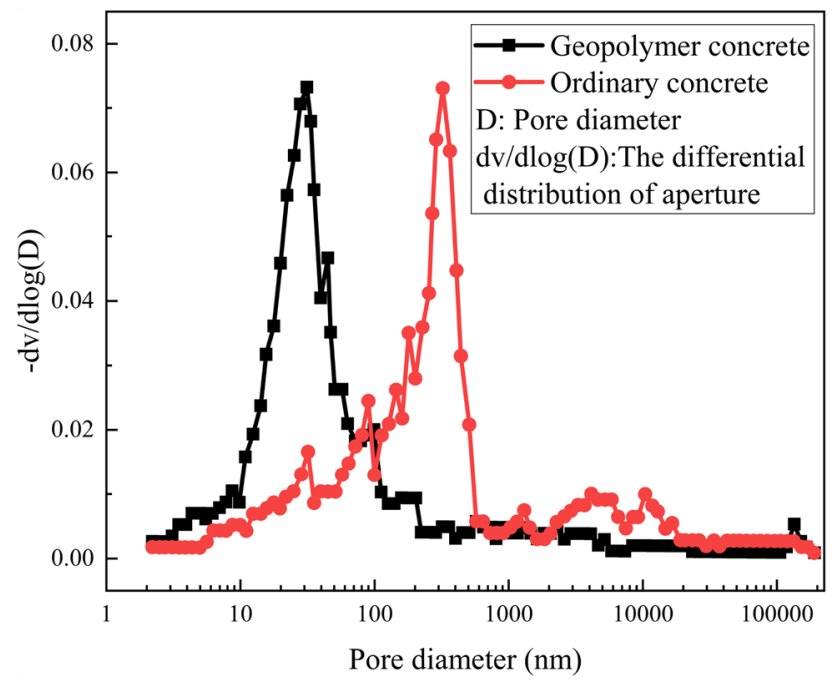

Fig. 6 Pore distribution of ordinary concrete and geopolymer concrete after 28 days hydration transition pores, capillary pores and macropores of geopolymers concrete $(30.61 \%$ and $33.30 \%)$ were relatively low. In terms of pore size, the average pore diameter and median pore diameter of geopolymer concrete were $134 \AA$ and $72 \AA$, respectively, while the average pore diameter and median pore diameter of ordinary concrete were $418 \AA$ and $213 \AA$, respectively. Therefore, the pore size of the geopolymer was significantly smaller than that of ordinary concrete, which was consistent with the results of impermeability.

SEM images of geopolymer and cement cured for 28 days are shown in Fig. 7a, b. Figure. 7a is a SEM of the hardened slurry at 28 days of curing of geopolymer specimens. The hydration products in the geopolymer concrete curing for 28 days were cross-connected with each other to form a whole, which was dense with few pores. There was only a small amount of unreacted red mud and BFS particles, which indicates that the 28-year-old geopolymer has a sufficient degree of hydration. Figure. $7 \mathrm{~b}$ is a SEM of the hardened slurry at 28 days of curing of ordinary concrete specimens. Compared with the geopolymer, the pores of cement hydration products were larger.

The mineral composition of red mud and geopolymer is shown in Fig. 8. From the diffraction peak position and intensity, it was found that red mud mainly contains hydrated garnet $\left(\mathrm{Ca}_{3} \mathrm{Al}_{2}\left(\mathrm{SiO}_{4}\right)(\mathrm{OH})_{8}\right)$, sodium aluminosilicate hydrate $\left(\mathrm{Na}_{12}\left[\left(\mathrm{AlO}_{2}\right)_{12}\left(\mathrm{SiO}_{2}\right)_{12}\right]_{27} \mathrm{H}_{2} \mathrm{O}\right)$, perovskite $\left(\mathrm{CaTiO}_{3}\right)$ and diaspore $\left(\mathrm{Al}_{2} \mathrm{O}_{3} \mathrm{H}_{2} \mathrm{O}\right)$. If $\mathrm{Al}$ in the hydrated garnet is partially replaced by $\mathrm{Fe}$, it will form water-containing calcium iron garnet $\left(\mathrm{Ca}_{3}\left(\mathrm{Fe}_{0.87} \mathrm{Al}_{0.13}\right)_{2}\left(\mathrm{SiO}_{4}\right)_{1.65}\right.$ $\left.(\mathrm{OH})_{5.4}\right)$. The titanium-bearing mineral usually associated with bauxite is ilmenite $\left(\mathrm{FeTiO}_{3}\right)$, which is a harmful impurity in the extraction of alumina. Generally, lime is added during leaching to transform it into perovskite $\left(\mathrm{CaTiO}_{3}\right)$. The diaspore monohydrate $\left(\mathrm{Al}_{2} \mathrm{O}_{3} \mathrm{H}_{2} \mathrm{O}\right)$ is left in the red mud from the diaspore monohydrate which is not eluted in the original bauxite.

It can be seen from the XRD patterns that the reaction products of the geopolymer were abrazite $\left(\mathrm{CaAl}_{2} \mathrm{Si}_{2} \mathrm{O}_{4} \cdot 4 \mathrm{H}_{2} \mathrm{O}\right)$, albite $\left(\mathrm{Na}_{2} \mathrm{O} \cdot \mathrm{Al}_{2} \mathrm{O}_{3} \cdot 6 \mathrm{SiO}_{2}\right)$, orthoclase $\left(\mathrm{K}\left[\mathrm{AlSi}_{3} \mathrm{O}_{8}\right]\right)$, anorthite $\left(\mathrm{CaAl}_{2} \mathrm{Si}_{2} \mathrm{O}_{8}\right)$ and illite. A large amount of aluminosilicate reaction products was generated in the geopolymer, such as abrazite. These substances were insoluble zeolite minerals which charactered high
Table 5 Pore structure of ordinary concrete and geopolymer concrete

\begin{tabular}{|c|c|c|c|c|c|c|}
\hline \multirow[t]{2}{*}{ Type } & \multirow[t]{2}{*}{ Total Porosity } & \multicolumn{3}{|c|}{ Pore distribution (\%) } & \multirow{2}{*}{$\begin{array}{l}\text { Average } \\
\text { pore size } \\
(\AA)\end{array}$} & \multirow{2}{*}{$\begin{array}{l}\text { Median } \\
\text { pore size } \\
(\AA ̊)\end{array}$} \\
\hline & & Gel pores & Transition hole & $\begin{array}{l}\text { Capillary } \\
\text { and large } \\
\text { holes }\end{array}$ & & \\
\hline Ordinary concrete & 33.35 & 6.12 & 55.56 & 38.32 & 418 & 213 \\
\hline Geopolymer concrete & 25.88 & 36.09 & 30.61 & 33.30 & 134 & 72 \\
\hline
\end{tabular}


Fig. 7 SEM images of red mud, geopolymer concrete and ordinary concrete: (a) geopolymer concrete; (b) ordinary concrete

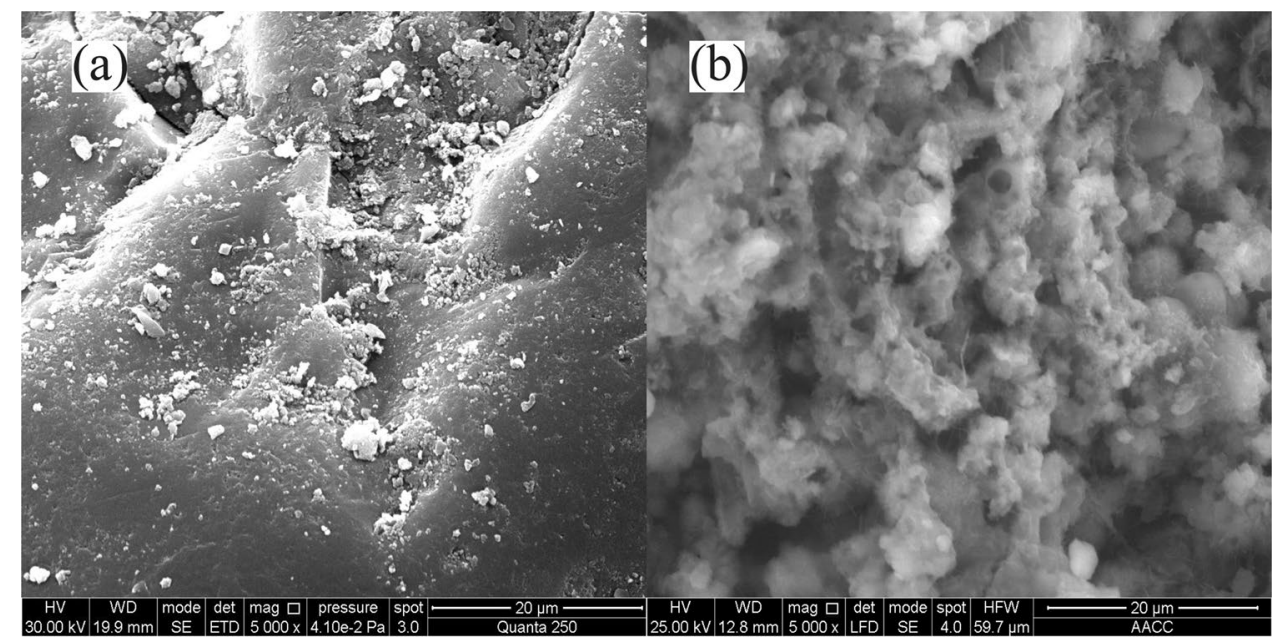

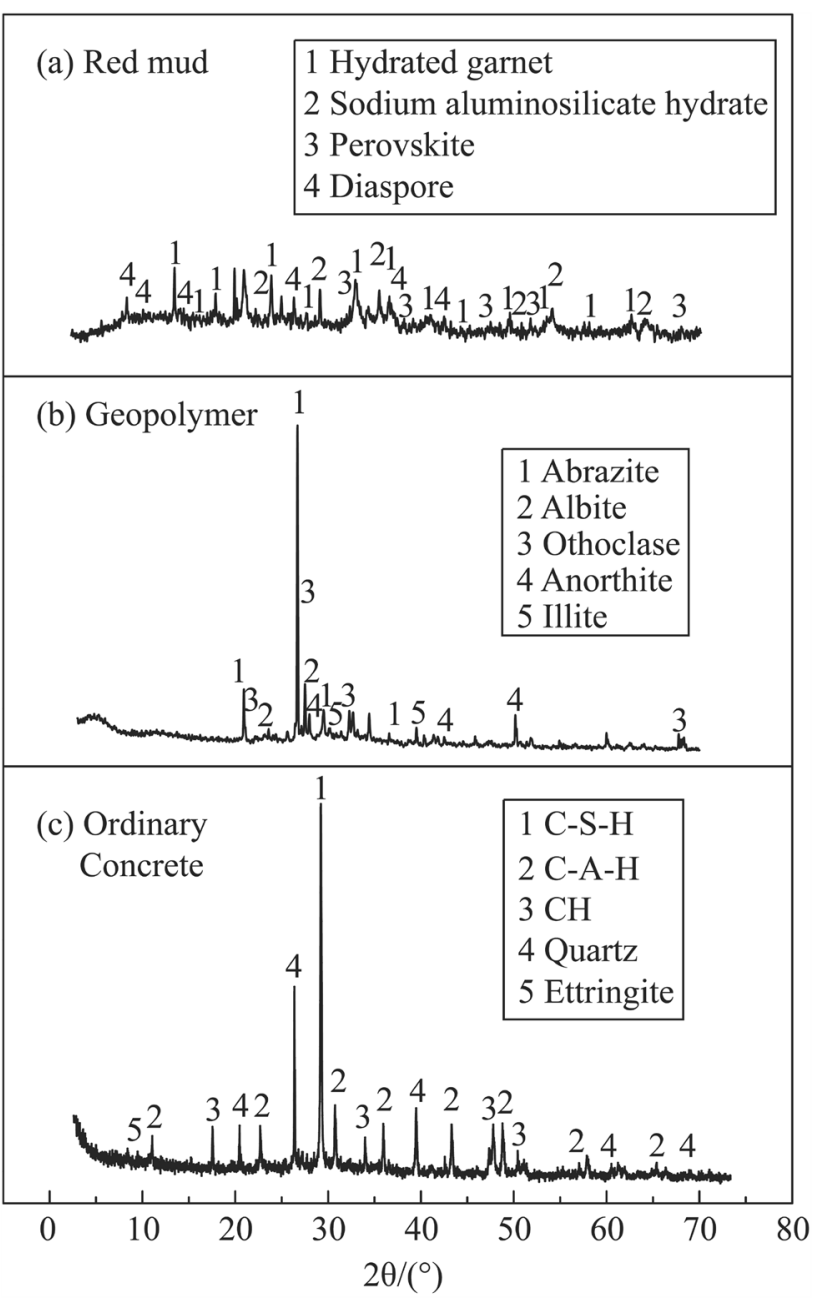

Fig. 8 XRD patterns of red mud and geopolymer concrete strength similar to rocks in the earth's crust. The main reason for the generation of this kind of substance was that it was generated by the reaction of $\mathrm{OH}^{-}$with the aluminosilicate components in red mud and BFS in a strongly alkaline environment. This kind of substance had a chain structure like an organic polymer and can react with mineral particles. The surface $\left[\mathrm{SiO}_{4}\right]^{4-}$ and $\left[\mathrm{AlO}_{4}\right]^{4-}$ tetrahedrons formed chemical bonds through dehydroxylation, which was the direct reason for their high strength and determines their excellent physical and chemical properties. For ordinary concrete (Fig. $8 \mathrm{C}$ ), the characteristic peaks are $\mathrm{C}-\mathrm{S}-\mathrm{H}$ gel, $\mathrm{C}-\mathrm{A}-\mathrm{H}$ gel, calcium hydroxide, ettringite, etc. Compared with Portland cement, geopolymer does not contain hydrated products of Portland cement, such as $\mathrm{Ca}(\mathrm{OH})_{2}$, hydrated calcium aluminate, ettringite, hydrated calcium sulfoaluminate and high alkaline $\mathrm{C}-\mathrm{S}-\mathrm{H}$ gel. That is, no $\mathrm{Ca}(\mathrm{OH})_{2}$, ettringite crystal phases exist in the geopolymer. However, the formation of silicon-aluminum octahedron significantly improves the strength and compactness of the geopolymer, where red mud provides the aluminum source and BFS provides the silicon source and aluminum source.

The FT-IR spectra for the geopolymer hydrated for 28 days were detected in wavenumber region between 4000 and $500 \mathrm{~cm}^{-1}$ in Fig. 9. The broad absorption band at $3440 \mathrm{~cm}^{-1}$ was related to the asymmetric stretching vibration of $\mathrm{OH}^{-}$. The absorption band near $1634 \mathrm{~cm}^{-1}$ was the bending vibration of $\mathrm{OH}^{-}$and the $\mathrm{OH}^{-}$came from the hydration product $\mathrm{C}-\mathrm{S}-\mathrm{H}$ generated by the reaction of red mud under the excitation of alkali. The strongest absorption peak in the sample was near $974 \mathrm{~cm}^{-1}$, where the asymmetric stretching vibration of $\mathrm{Si}-\mathrm{O}-\mathrm{Si}, \mathrm{O}-\mathrm{Si}-\mathrm{O}$ and $\mathrm{Si}-\mathrm{O}-\mathrm{Al}$ was found. The second strong absorption region was $600 \mathrm{~cm}^{-1} \sim 400 \mathrm{~cm}^{-1}$ and the strongest absorption peak is at $455 \mathrm{~cm}^{-1}$, which was the bending vibration of $\mathrm{Si}-\mathrm{O}$ bond. The absorption band in the range 


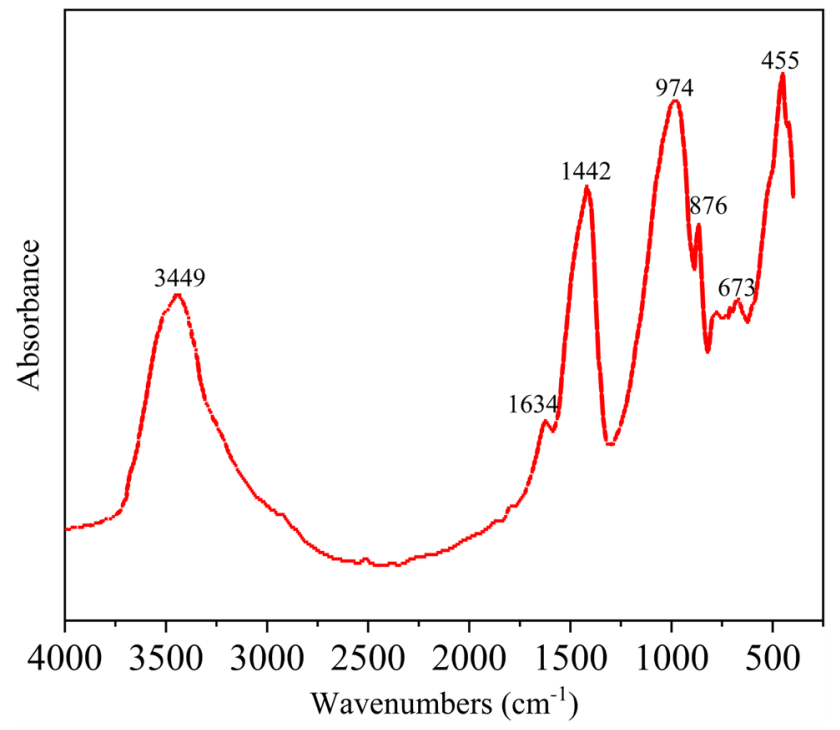

Fig. 9 FTIR spectra of red mud-blast furnace slag-based geopolymer concrete

of $600 \mathrm{~cm}^{-1} \sim 800 \mathrm{~cm}^{-1}$ was caused by: 1) the symmetric stretching vibration of the tetrahedron 2 ) the $\mathrm{Si}-\mathrm{O}-\mathrm{Si}$ stretching vibration 3 ) the $\mathrm{Al}-\mathrm{O}-\mathrm{Si}$ stretching vibration. Between wavenumber region $600 \mathrm{~cm}^{-1} \sim 800 \mathrm{~cm}^{-1}$ many tiny absorption peak occurred, which caused by the vibration of $\mathrm{Al}-\mathrm{O}$ in [AlO4]. This indicates that under the action of $\mathrm{OH}^{-}, \mathrm{Al}$ in the red mud dissolved out, into the matrix phase involved in bonding, generated by $\mathrm{Si}-\mathrm{O}-\mathrm{Al}$ and $\mathrm{Al}-\mathrm{Si}-\mathrm{O}-\mathrm{O}$ mineral polymer skeleton composed of $\mathrm{Si}-\mathrm{O}-\mathrm{Al}-\mathrm{O}$ (single), $\mathrm{Si}-\mathrm{Al}-\mathrm{O}-\mathrm{O}-\mathrm{Si}-\mathrm{O}$ (double chain) and three chain Si-O-Al-O-Si-O-Si-O.

\section{Conclusion}

1. The strength grade of concrete prepared with a geopolymer can reach C30 grade ( $>30 \mathrm{MPa}$ ) and can be used for structural load-bearing members.

2. The permeability coefficients of geopolymer concrete and ordinary concrete were $1.1 \times 10^{-14} \mathrm{~m} / \mathrm{s}$ and $3.4 \times 10^{-14} \mathrm{~m} / \mathrm{s}$, respectively. The permeability resistance of geopolymer concrete was better than that of ordinary concrete.

3. The hydration products in the geopolymer concrete cured for 28 days were cross-connected with each other to form a whole, which was dense with few pores. The formation of silicon-aluminum octahedron significantly improved the strength and compactness of the geopolymer, where red mud with small particle size provided the aluminum source and BFS provided the silicon source, aluminum source and calcium source.
Acknowledgements This work was supported by the National Natural Science Foundation of China under Grant 51972337.

\section{Compliance with ethical standards}

Conflict of interest The authors declare no conflict of interest.

Open Access This article is licensed under a Creative Commons Attribution 4.0 International License, which permits use, sharing, adaptation, distribution and reproduction in any medium or format, as long as you give appropriate credit to the original author(s) and the source, provide a link to the Creative Commons licence, and indicate if changes were made. The images or other third party material in this article are included in the article's Creative Commons licence, unless indicated otherwise in a credit line to the material. If material is not included in the article's Creative Commons licence and your intended use is not permitted by statutory regulation or exceeds the permitted use, you will need to obtain permission directly from the copyright holder. To view a copy of this licence, visit http://creativecommons. org/licenses/by/4.0/.

\section{Reference}

1. Liu XM, Zhang N (2011) Utilization of red mud in cement production: a review. Waste Manage. Res 29(10):1053-1063. https ://doi.org/10.1177/0734242x11407653

2. Gautam M, Agrawal M (2017) Phytoremediation of metals using vetiver (Chrysopogon zizanioides (L.) Roberty) grown under different levels of red mud in sludge amended soil. J Geochem Explor 182:218-227. https://doi.org/10.1016/j.gexpl 0.2017 .03 .003

3. Geng JJ, Zhou M, Zhang T, Wang WX, Wang T, Zhou X, Wang XS, Hou HB (2017) Preparation of blended geopolymer from red mud and coal gangue with mechanical co-grinding preactivation. Mater Struct. 50(2):109. https://doi.org/10.1617/s1152 7-016-0967-5

4. Zhang R, Zheng SL, Ma SH, Zhang Y (2011) Recovery of alumina and alkali in Bayer red mud by the formation of andraditegrossular hydrogarnet in hydrothermal process. J Hazard Mater. 189(3):827-835. https://doi.org/10.1016/j.jhazmat.2011.03.004

5. Wei GT, Shao LH, Mo JH, Li ZM, Zhang LY (2017) Preparation of a new Fenton-like catalyst from red mud using molasses wastewater as partial acidifying agent. Environ Sci Pollut R 24(17):1506715077. https://doi.org/10.1007/s11356-017-9126-y

6. Li J, Xu L, Sun PP, Zhai PY, Chen XP, Zhang H, Zhang ZS, Zhu WC (2017) Novel application of red mud: Facile hydrothermalthermal conversion synthesis of hierarchical porous $\mathrm{AlOOH}$ and Al2O3 microspheres as adsorbents for dye removal. Chem Eng J. 321:622-634. https://doi.org/10.1016/j.cej.2017.03.135

7. Hua YM, Heal KV, Friesl-HanI W (2017) The use of red mud as an immobiliser for metal/metalloid-contaminated soil: A review. J Hazard Mater. 325:17-30. https://doi.org/10.1016/j.jhazm at.2016.11.073

8. Yang ZT, Mocadlo R, Zhao MX, Sisson RD, Tao MJ, Liang JY (2019) Preparation of a geopolymer from red mud slurry and class $F$ fly ash and its behavior at elevated temperatures. Constr Build Mater 221:308-317. https://doi.org/10.1016/j.conbuildma t.2019.06.034

9. Singh B, Ishwarya G, Gupta M, Bhattacharyya SK (2015) Geopolymer concrete: A review of some recent developments. Constr Build Mater. 85:78-90. https://doi.org/10.1016/j.conbuildma t.2015.03.036 
10. Majidi B (2009) Geopolymer technology, from fundamentals to advanced applications: a review. Mater Technol. 24(2):79-87. https://doi.org/10.1179/175355509x449355

11. He J, Jie YX, Zhang JH, Yu YZ, Zhang GP (2013) Synthesis and characterization of red mud and rice husk ash-based geopolymer composites. Cement Concrete Comp. 37:108-118. https:// doi.org/10.1016/j.cemconcomp.2012.11.010

12. Kumar A, Kumar S (2013) Development of paving blocks from synergistic use of red mud and fly ash using geopolymerization. Constr Build Mater 38:865-871. https://doi.org/10.1016/j.conbu ildmat.2012.09.013

13. Kaya K, Soyer-Uzun S (2016) Evolution of structural characteristics and compressive strength in red mud-metakaolin based geopolymer systems. Ceram Int. 42(6):7406-7413. https://doi. org/10.1016/j.ceramint.2016.01.144

14. Ke XY, Bernal SA, Ye N, Provis JL, Yang JK (2015) One-Part Geopolymers Based on Thermally Treated Red Mud/NaOH Blends. J Am Ceram Soc. 98(1):5-11. https://doi.org/10.1111/jace.13231

15. Choo H, Lim S, Lee W, Lee C (2016) Compressive strength of onepart alkali activated fly ash using red mud as alkali supplier. Constr Build Mater 125:21-28. https://doi.org/10.1016/j.conbuildma t.2016.08.015

16. Ye N, Yang JK, Ke XY, Zhu J, Li YL, Xiang C, Wang HB, Li L, Xiao B (2014) Synthesis and Characterization of Geopolymer from Bayer Red Mud with Thermal Pretreatment. J Am Ceram Soc 97(5):1652-1660. https://doi.org/10.1111/jace.12840

17. Ye N, Yang JK, Liang S, Hu Y, Hu JP, Xiao B, Huang QF (2016) Synthesis and strength optimization of one-part geopolymer based on red mud. Constr Build Mater. 111:317-325. https:// doi.org/10.1016/j.conbuildmat.2016.02.099

18. Hu W, Nie QK, Huang BS, Shu X, He Q (2018) Mechanical and microstructural characterization of geopolymers derived from red mud and fly ashes. J Clean Prod. 186:799-806. https://doi. org/10.1016/j.jclepro.2018.03.086

19. Hajjaji W, Andrejkovicova S, Zanelli C, Alshaaer M, Dondi M, Labrincha JA, Rocha F (2013) Composition and technological properties of geopolymers based on metakaolin and red mud. Mater Des 52:648-654. https://doi.org/10.1016/j.matde s.2013.05.058

20. Ribeiro DV, Labrincha JA, Morelli MR (2012) Effect of the addition of red mud on the corrosion parameters of reinforced concrete. Cement Concrete Res. 42(1):124-133. https://doi.org/10.1016/j. cemconres.2011.09.002

21. Diaz B, Freire L, Novoa XR, Perez MC (2015) Chloride and CO2 transport in cement paste containing red mud. Cement Concrete Comp 62:178-186. https://doi.org/10.1016/j.cemconcomp .2015.02.011

22. Chandrappa AK, Biligiri KP (2016) Comprehensive investigation of permeability characteristics of pervious concrete: A hydrodynamic approach. Constr Build Mater. 123:627-637. https://doi. org/10.1016/j.conbuildmat.2016.07.035

23. Mulqueen J (2005) The flow of water through gravels. Irish Journal of Agricultural and Food Research 44(1):83-94

24. Yoo J-H, Lee H-S, Ismail MA (2011) An analytical study on the water penetration and diffusion into concrete under water pressure. Constr Build Mater. 25(1):99-108. https://doi.org/10.1016/j. conbuildmat.2010.06.052

Publisher's Note Springer Nature remains neutral with regard to jurisdictional claims in published maps and institutional affiliations. 